\title{
LETTER
}

\section{Determinants of helicopter benefit for the transport of severe trauma patients}

\author{
Thibaut Desmettre ${ }^{1 *}$, Claire Bonithon-Kopp ${ }^{2}$, Marc Freysz ${ }^{3}$ and French Intensive Care Recorded in Severe Trauma
}

\author{
See related commentary by Galvagno, http:/ccforum.com/content/17/4/169
}

Recently, Galvagno commented on the paper of Andruszkow and colleagues and summarized the studies using multivariate logistic regression to compare helicopter transport (HT) versus ground transport of trauma patients $[1,2]$. The authors did not mention our analysis of 1,958 trauma patients ( $26 \%$ transported by HT) specifically performed to investigate the influence of the mode of transport from the database of the French Intensive care Recorded in Severe Trauma study [3,4]. Compared with ground transport, HT patients were more intensively treated in the prehospital phase. The need for emergency surgical procedures and overall head surgical procedures until discharge from hospital were higher in the HT group. After adjustment for initial status, the risk of death before hospital discharge was significantly lower for HT (odds ratio $=0.68$, 95\% confidence interval $=0.47$ to $0.98, P=0.035$ ), whichever model was considered. Increasing age, Glasgow Coma Scale $<14$, systolic blood pressure $<90 \mathrm{mmHg}$, oxygen saturation $<90 \%$, suspected trauma severity and aggressive therapy remained significant factors for death, whereas gender and time to hospital admission did not enter the regression model.

HT seems to act as an accelerator of care within the hospital, probably with a higher quality of care by the team in charge of the patient on arrival at the trauma center. A high level of prehospital care and more overall surgical procedures in hospital cannot alone explain the benefit of HT. Detailed analysis of the pattern of prehospital care is needed to explore other factors. Finally, HT is more expensive than ground transport and a cost-effectiveness analysis must be taken into account in further studies.

\footnotetext{
* Correspondence: tdesmettre@chu-besancon.fr

'Université de Franche Comté, CHU Besançon, Hôpital J Minjoz, Urgences/

SAMU25, 1 Bd Fleming, 25030, Besançon cedex, France

Full list of author information is available at the end of the article
}

Abbreviations

HT: Helicopter transport.

\section{Competing interests}

The authors declare that they have no competing interests.

\section{Author details}

'Université de Franche Comté, CHU Besançon, Hôpital J Minjoz, Urgences/ SAMU25, 1 Bd Fleming, 25030, Besançon cedex, France. ${ }^{2}$ INSERM CIE 01, CHU Dijon, Centre d'Investigation Clinique-Epidémiologie Clinique, Dijon 21000, France. ${ }^{3} \mathrm{CHU}$ Dijon, Hôpital du Bocage, Département de Médecine d'Urgence, Université de Bourgogne, Dijon 21000, France.

\section{Published: 02 Oct 2013}

\section{References}

1. Galvagno SM Jr: Comparative effectiveness of helicopter emergency medical services compared to ground emergency medical services. Crit Care 2013, 17:169.

2. Andruszkow H, Lefering R, Frink M, Mommsen P, Zeckey C, Rahe K, Krettek C, Hildebrand F: Survival benefit of helicopter emergency medical services compared to ground emergency medical services in traumatized patients. Crit Care 2013, 17:R124.

3. Desmettre T, Yeguiayan JM, Coadou H, Jacquot C, Raux M, Vivien B, Martin C, Bonithon-Kopp C, Freysz M, French Intensive Care Recorded in Severe Trauma: Impact of emergency medical helicopter transport directly to a university hospital trauma center on mortality of severe blunt trauma patients until discharge. Crit Care 2012, 16:R170.

4. Yeguiayan JM, Garrigue D, Binquet C, Jacquot C, Duranteau J, Martin C, Rayeh F, Riou B, Bonithon-Kopp C, Freysz M, French Intensive Care Recorded in Severe Trauma Study: Medical pre-hospital management reduces mortality in severe blunt trauma: a prospective epidemiological study. Crit Care 2011, 15:R34.

\section{$10.1186 / \mathrm{cc} 13031$}

Cite this article as: Desmettre et al:: Determinants of helicopter benefit for the transport of severe trauma patients. Critical Care 2013, 17:454 